University of Nebraska - Lincoln

DigitalCommons@University of Nebraska - Lincoln

4-2004

\title{
Parallopharynx spp. (Trematoda: Digenea: Plagiorchioidea) in Iguanian Lizards from the Área de Conservación Guanacaste, Guanacaste, Costa Rica, including Parallopharynx matternae n. sp. in Basiliscus basiliscus (Squamata: Iguania: Corytophanidae)
}

\author{
David Zamparo \\ University of Toronto \\ Daniel R. Brooks \\ University of Toronto,dnlbrooks@gmail.com \\ Vasyl Tkach \\ University of North Dakota \\ Beatriz Rodriguez \\ Universidad de Costa Rica
}

Follow this and additional works at: https://digitalcommons.unl.edu/parasitologyfacpubs

Part of the Parasitology Commons

Zamparo, David; Brooks, Daniel R.; Tkach, Vasyl; and Rodriguez, Beatriz, "Parallopharynx spp. (Trematoda: Digenea: Plagiorchioidea) in Iguanian Lizards from the Área de Conservación Guanacaste, Guanacaste, Costa Rica, including Parallopharynx matternae n. sp. in Basiliscus basiliscus (Squamata: Iguania: Corytophanidae)" (2004). Faculty Publications from the Harold W. Manter Laboratory of Parasitology. 255. https://digitalcommons.unl.edu/parasitologyfacpubs/255

This Article is brought to you for free and open access by the Parasitology, Harold W. Manter Laboratory of at DigitalCommons@University of Nebraska - Lincoln. It has been accepted for inclusion in Faculty Publications from the Harold W. Manter Laboratory of Parasitology by an authorized administrator of DigitalCommons@University of Nebraska - Lincoln. 


\title{
PARALLOPHARYNX SPP. (TREMATODA: DIGENEA: PLAGIORCHIOIDEA) IN IGUANIAN LIZARDS FROM THE AREA DE CONSERVACIÓN GUANACASTE, GUANACASTE, COSTA RICA, INCLUDING PARALLOPHARYNX MATTERNAE N. SP. IN BASILISCUS BASILISCUS (SQUAMATA: IGUANIA: CORYTOPHANIDAE)
}

\author{
David Zamparo, Daniel R. Brooks, Vasyl Tkach*, and Beatriz Rodriguez $†$ \\ Department of Zoology, University of Toronto, Toronto, Ontario, M5S 3G5, Canada. e-mail: zamparo@zoo.utoronto.ca
}

\begin{abstract}
We report 3 species of the digenean genus Parallopharynx, 1 previously undescribed, from the Area de Conservación Guanacaste (ACG) in northwestern Costa Rica. Parallopharynx gonzalezi, which was originally described in Basiliscus sp. and Ctenosaura similis from central Costa Rica, inhabits C. quinquecarinata; P. jonesi, originally described in Anolis lionotus (syn. Norops oxylophus) from Nicaragua, inhabits $N$. oxylophus, $N$. biporcatus, and Basiliscus basiliscus; and the new species, which inhabits B. basiliscus. Parallopharynx matternae $\mathrm{n}$. sp. differs from all other members of the genus by having a metraterm extending posteriad from the genital pore to the posterior margin of the ventral sucker, whereas in $P$. arctus and $P$. gonzalezi, the metraterm never surpasses the midlevel of the ventral sucker and in $P$. jonesi it never passes the anterior margin of the ventral sucker, and by having an oral sucker that does not exceed $150 \mu \mathrm{m}$ in diameter with a subsequent greater oral-ventral sucker width ratio ranging from 1:0.88-1.12 (averaging 1:1), whereas values range from 1:0.71-0.83 for $P$. gonzalezi and $P$. arctus, and from 1:0.59-0.68 for P. jonesi. Parallopharynx spp. possesses Y-shaped excretory vesicles with a long central stem and short arms bifurcating immediately posterior to the ovary; similar to those found in members of the Telorchiidae. Additional similarities in the relative positions of the gonads and the structure of the cirrus sac and metraterm indicate a close relationship between Parallopharynx and members of the Telorchiidae.
\end{abstract}

Caballero (1946) proposed Parallopharynx for $P$. arctus Caballero, 1946 on the basis of a single specimen inhabiting the intestine of the corytophanid lizard Basiliscus vittatus Wiegmann, 1828 from Guatemala. Neiland (1961) reported an additional specimen in an unidentified iguanid from Nicaragua, stating "though generally somewhat larger, agrees in all essential features with Caballero's Guatemalan type specimen". Two additional species have been described: Parallopharynx gonzalezi Brenes, Arroyo, and Montero-Gei, 1960 in the corytophanid lizard Basiliscus sp., and the iguanid lizard Ctenosaura s. similis Gray, 1831 from Rio Grande, Atenas, Provincia de Alajuela, Costa Rica, on the basis of "numerous" specimens (Brenes et al., 1960); and Parallopharynx jonesi Ubelaker, 1965 in the cloaca of the polychrotid lizard Anolis lionotus Taylor 1956 (= Norops oxylophus Guyer and Savage, 1986) from Nicaragua, on the basis of 20 specimens (Ubelaker, 1965). Thatcher (1963) redescribed $P$. arctus from specimens obtained from $B$. vittatus from Tabasco, Mexico, emending the generic diagnosis to include the presence of oral lappets, a muscular prepharynx, a spinose tegument, and a Y-shaped excretory vesicle.

In this contribution from the activities of the inventory of eukaryotic parasites of vertebrates of the Area de Conservación Guanacaste (ACG) in northwestern Costa Rica, we report $P$. gonzalezi, $P$. jonesi, and a previously undescribed species of Parallopharynx.

\section{MATERIALS AND METHODS}

Worms were collected alive, from recently killed hosts, killed and fixed by shaking in hot formalin, then stored in $70 \%$ ethanol. Specimens were stained with Mayer hematoxylin, dehydrated, and mounted in Canada balsam. The first values stated are the range, with mean values in parentheses. All measurements are in micrometers unless otherwise stat-

Received 8 July 2003; revised 29 September 2003; accepted 29 September 2003

* Department of Biology, University of North Dakota Grand Forks, P.O. Box 9019, Grand Forks, North Dakota 58202-9019.

$\dagger$ Escuela de Microbiologia, Universidad de Costa Rica, San Pedro, Costa Rica. ed. $\mathrm{TBL}=$ total body length. All figures were made with the aid of a drawing tube. The following abbreviations are used: Colección Nacional de Helmintos, Instituto de Biología, Universidad Nacional Autónoma de Mexico, CNHE; United States National Parasite Collection, Beltsville, Maryland, USNPC; Colección Helmintológica de Costa Rica, CHCR. The following specimens were examined for comparison: holotype of $P$. gonzalezi (CHCR 200-27); holotype of $P$. jonesi (USNPC 60493); voucher specimens of $P$. arctus (CNHE 912,3) and (USNPC 92188). Information concerning host identifications by specialists, digital images of hosts, and the disposition of host specimens and tissues is available at http://brooksweb.zoo.utoronto.ca/index.html.

\section{DESCRIPTION}

Parallopharynx matternae n. sp.

(Figs. 1-2)

Description (on the basis of 6 mature specimens): Body elongate, 3.7-7.1 (5.8) mm long, 0.30-0.50 (0.41) mm wide. Maximum width near midbody. Tegument spinose. Oral sucker subterminal, nearly round, 120-150 (135) long, 125-145 (128) wide, with 1 pair of lappets on lateral margin. Prepharynx 75150 (120) long. Pharynx 115-175 (144) long, 65-100 (80) wide, with 3 flaps extending into prepharynx from anterior margin. Oral sucker to pharynx ratio, 1:0.52-0.80 (1:0.62). Esophagus short, 25-50 long. Intestinal bifurcation 6-11\% (8\%) (TBL) from anterior end. Ceca long and narrow, sinistral cecum longer than dextral, extending to within $2-4 \%$ (3\%) TBL of posterior end, whereas dextral cecum extends to within 6-12\% (9\%) TBL of posterior end. Forebody 17-24\% (20\%) TBL. Ventral sucker 110-140 (129) long, 110-140 (130) wide. Oral sucker-ventral sucker ratio, 1:0.88-1.12 (1:1.01). Testes postacetabular, intercecal, tandem. Anterior testis 155-210 (180) long, 195-270 (242) wide, 61-74\% (68\%) TBL from anterior end; posterior testis 140-225 (188) long, 180-275 (238) wide, $75-83 \%(78 \%)$ TBL from anterior end. Testes 350-800 (530) apart. One specimen with extra medial testis, 90 long by 145 wide. Genital pore median, anterior to ventral sucker, $14-21 \%$ (18\%) TBL from anterior end. Cirrus sac dorsal and posterodorsal to ventral sucker, straight, 525-910 (733) long, 60-105 (89) wide, containing voluminous coiled seminal vesicle, well- 

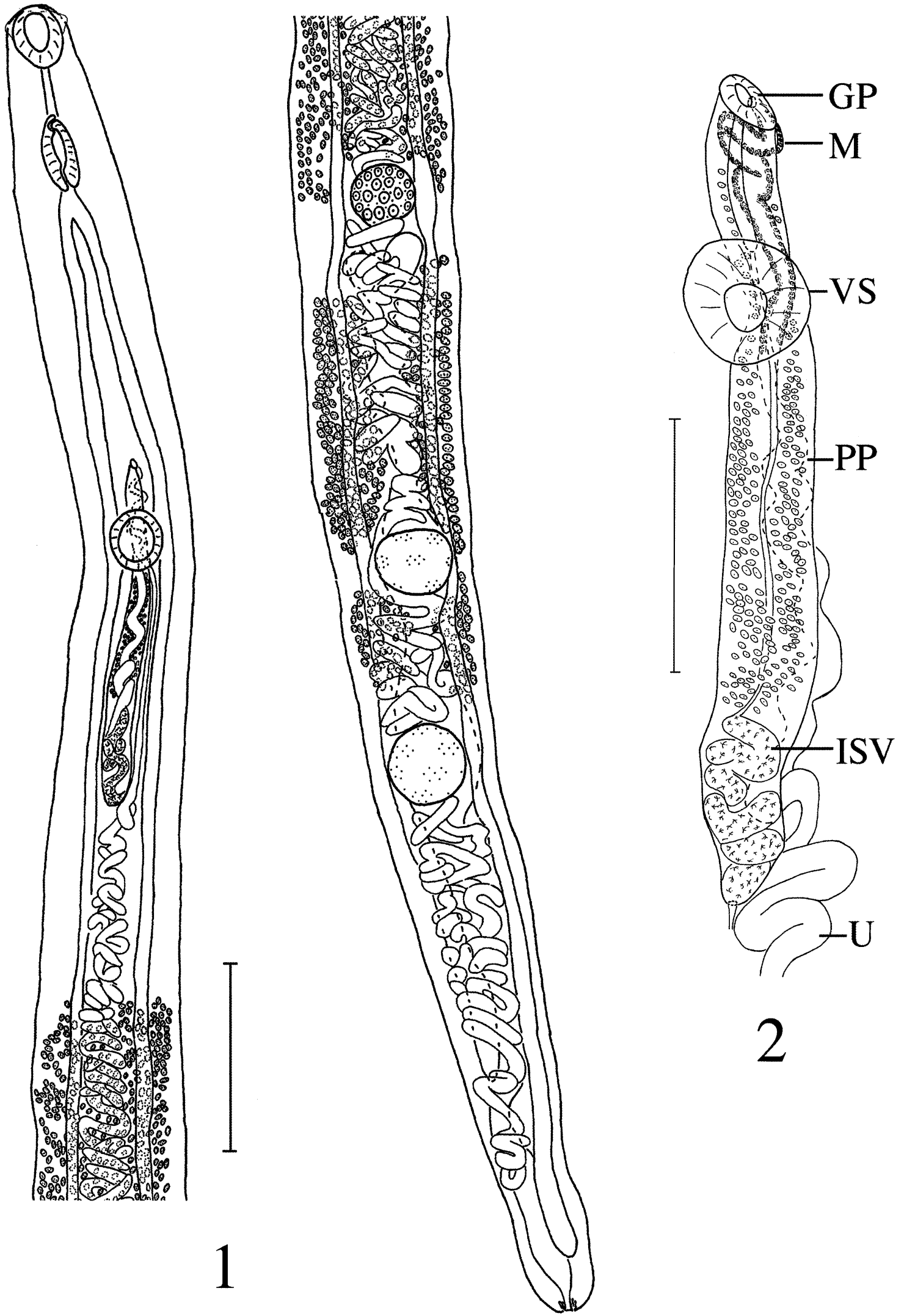

FIGURES 1-2. Parallopharynx matternae, n. sp. 1. Ventral view of holotype. Bar $=500 \mu \mathrm{m}$. 2. Terminal genitalia. GP, genital pore; ISV, internal seminal vesicle; M, metraterm; PP, pars prostatica; VS, ventral sucker; U, uterus. Bar $=250 \mu \mathrm{m}$. 
developed pars prostatica, and cirrus. Ratio of cirrus sac widthlength, 1:6.7-11.1. Posterior end of cirrus sac approximately $3-$ 5 ventral sucker diameters or $26-32 \%(29 \%)$ TBL, posterior to ventral sucker (Fig. 2). Ovary spherical, 110-150 (138) long, 135-210 (175) wide, median, two-thirds distance from ventral sucker to anterior testis, or 51-57\% (53\%) TBL from anterior end. Ootype immediately posterior to ovary, dorsal to seminal receptacle. Uterine loops intercecal, posteriormost extent of uterus 2-6\% (6\%) TBL from posterior end, between cecal ends. Vitelline fields extending anteriorly from level between ventral sucker and ovary, beginning 29-42\% (36\%) TBL from anterior end, terminating posteriorly $15-25 \%$ (19\%) TBL from posterior end. Vitelline fields confluent dorsally from anteriormost extent to level of ovary, postovarian vitelline follicles partially encircling ceca dorsally. Both vitelline fields extending posterior to posterior testis in 2 specimens; 1 field extending posterior to posterior testis in 2 specimens, sinistrally in 1 and dextrally in 1 ; vitelline fields terminating just anterior to posterior testis in 2 specimens. Vitelline fields interrupted by ovary and testes such that, when vitellaria extend posterior to testes, there are 4 groups of vitellaria. Metraterm well developed, glandular and muscular, dorsal to cirrus sac, sinuous, 175-250 (200) long, extending from midlevel to posterior margin of ventral sucker. Excretory pore terminal, bladder Y-shaped, bifurcating immediately postovarian. Eggs 13-18 (15) long $\times$ 8-10 (9) wide.

\section{Taxonomic summary}

Type host: Basiliscus basiliscus Laurenti, 1758 (Squamata: Iguania: Corytophanidae).

Prevalence; Intensity; Site of infection: $\mathrm{P}=2$ of $3 ; \mathrm{I}=6$ and 4; small intestine.

Type locality: Quebrada Aserradero, Rio Tempisquito, Sector Centeno, ACG, Guanacaste Province, Costa Rica, LN 318034, LE 366950 (Lambert coordinates).

Type material: Holotype, USNPC 94006; paratypes, USNPC 94007.

Etymology: The new species is named for Michelle Mattern, Department of Zoology, University of Toronto.

\section{Remarks}

Parallopharynx matternae differs from all other members of the genus by having an oral sucker diameter less than 150 , with subsequent larger oral-ventral sucker width ratio of 1:0.88-1.12 (averaging 1:1), whereas values range from 1: $0.71-0.83$ for $P$. gonzalezi and $P$. arctus, and from 1:0.59-0.68 for $P$. jonesi. In addition, the metraterm of $P$. matternae extends posteriorly to the posterior margin of the ventral sucker, whereas the metraterm of $P$. arctus and $P$. gonzalezi never reaches posterior to the midlevel of the ventral sucker, and that of $P$. jonesi does not extend past the anterior margin of the ventral sucker. Our specimens of $P$. matternae differ from all other species in several meristic traits: suckers, both oral and ventral, do not exceed 150 in diameter, and the pharynx does not exceed 100 in width, approximately half the size of those traits in similarly sized individuals of other species in the genus. Finally, eggs of $P$. matternae do not exceed $18 \times 10$, whereas in all other members the egg size ranges from $20-25 \times 12-18$.

Parallopharynx matternae appears to be most similar to $P$. arctus. Both species have relatively narrower bodies, averaging
6-8\% of TBL, compared with 12-20\% TBL for $P$. jonesi and $P$. gonzalezi, cirrus sac extending more than 2 ventral sucker lengths posterior to the posterior margin of the ventral sucker. Additionally, the testes of specimens of $P$. matternae are more than 350 apart and those of $P$. arctus more than 500 apart, whereas they are less than 200 apart in $P$. gonzalezi, (although never contiguous, they are at least 1.5 testis diameters apart); in $P$. jonesi, the testes are contiguous, or nearly so, never more than 1.5 testis diameters apart.

\section{Parallopharynx gonzalezi Brenes, Arroyo, and Montero- Gei, 1960}

Hosts: Ctenosaura quinquecarinata Gray, 1842 (Squamata: Iguania: Iguanidae), new host.

Prevalence; intensity: One of $2 ; 1$.

Locality: Rio Cuajiniquil, Sector Murcielago, ACG, $32^{\circ} 50.35^{\prime} \mathrm{N}, 35^{\circ} 49.85^{\prime} \mathrm{W}$.

Site of infection: Small intestine.

Voucher specimen: USNPC No. 94008.

\section{Parallopharynx jonesi Ubelaker, 1965}

Host: Norops oxylophus Cope, 1875 (Squamata: Iguania: Polychrotidae), N. biporcatus Guyer \& Savage, 1986; Norops sp.; B. basiliscus Laurenti, 1758 (Squamata: Iguania: Corytophanidae.

Prevalence; intensity: Norops oxylophus $(1$ of 3,1$)$ at Estacion Caribe, (1 of 2, 2) at La Argentina, (1 of 4,1) at Quebrada Serrano; $N$. biporcatus (1 of 3,1$)$ at Estacion Caribe; Norops sp. $(1$ of 3,6$)$ at Estacion Caribe; Norops sp. $(1$ of 7,4$)$ at Rio Negro; $B$. basiliscus (1 of 2,12 ) at Rio Cuajiniquil.

Localities: Estacion Caribe, Sector Caribe, ACG, $32^{\circ} 03.13^{\prime} \mathrm{N}, 39^{\circ} 68.15^{\prime} \mathrm{W}$; La argentina, Sector San Gerardo, ACG, $32^{\circ} 01.07^{\prime} \mathrm{N}, 38^{\circ} 49.68^{\prime} \mathrm{W}$; Quebrada Serrano, Sector Rio Mena, ACG, $33^{\circ} 11.77^{\prime} \mathrm{N}, 37^{\circ} 73.64^{\prime} \mathrm{W}$; Rio Negro, Sector Caribe, ACG, $32^{\circ} 05.72^{\prime} \mathrm{N}, 39^{\circ} 37.75^{\prime} \mathrm{W}$; Rio Cuajiniquil, Sector Santa Rosa, ACG, $10^{\circ} 50.44^{\prime} \mathrm{N}, 85^{\circ} 36.26^{\prime} \mathrm{W}$.

Site of infection: Small intestine.

Voucher specimens: USNPC No. 94009 (from N. oxylophus).

\section{DISCUSSION}

Parallopharynx has been placed in the Macroderoididae by a majority of authors who have considered the genus (Caballero, 1946; Brenes et al., 1960; Neiland, 1961; Ubelaker, 1965; Yamaguti, 1971). The primary diagnostic feature of the Macroderoididae has been the possession of an I-, rather than Y-, or V-shaped excretory vesicle. Thatcher (1963) and Ubelaker (1965) described the excretory vesicle of $P$. arctus and $P$. jonesi, respectively, as Y-shaped, resembling those of Plagiorchis spp., and Thatcher (1963) placed the genus in the Plagiorchiidae. Thatcher (1963) described $P$. arctus as having anterior arms of the excretory vesicle extending as far anteriorly as the level of the pharynx, but our examination of 2 specimens from his study convinced us that Thatcher (1963) included the main collecting ducts of the excretory system as part of the excretory vesicle. In addition to specimens of $P$. jonesi, $P$. gonzalezi, and $P$. matternae, collected during our inventory in the ACG, we have examined the holotypes of $P$. gonzalezi and $P$. jonesi, as well as voucher specimens of $P$. arctus. All specimens possess 
long excretory vesicles with short, but distinct, Y-shaped anterior ends bifurcating at the level of the posterior margin of the ovary. This particular configuration of the excretory vesicle is similar to that of members of the Telorchiidae. Parallopharynx spp. further resembles telorchiids by having prominent glandular and muscular metraterms, which are unusual among plagiorchiform digeneans. They are also similar in traits that are more general among plagiorchiforms, such as elongate to filiform bodies, gonads in the hindbody with postovarian testes, genital pores anterior to the ventral sucker, and elongate cirrus sacs extending posteriad and dorsal to the ventral sucker and containing a coiled seminal vesicle and well-developed pars prostatica.

Morphologically based phylogenetic systematic assessment of familial and suprafamilial relationships among digeneans (Brooks et al., 1985, 1989; Brooks and McLennan, 1993) produced a small number of traits supporting a possible clade comprising the Auridistomidae, Rhytidotidae, Telorchiidae, and Ochetosomatidae. Members of these families possess a prominent glandular and muscular metraterm, a cirrus sac containing a coiled seminal vesicle, and pars prostatica that is both long and surrounded by numerous large gland cells, and inhabit a variety of non-archosaurian reptiles, i.e., turtles and squamates. Furthermore, all members of Auridistomidae, Rhytidotidae, and at least 1 member of Telorchiidae, possess lateral lappets on the oral sucker, similar in structure to those found in all species of Parallopharynx. Members of all 4 families posses Y-shaped excretory vesicles, but those of the aurdistomids and rhytidotids have diverticulate walls with arms reaching anteriorly into the forebody. It thus appears that Parallopharynx is closely related to telorchiids. As is the case for most digeneans, few life cycles are known for these taxa, and no life cycles are known for Parallopharynx spp. However, all species of ochetosomatids, telorchiids, and auridistomids for which life cycles are known (Yamaguti, 1975; Schell, 1985), use anurans, especially larvae, as second intermediate hosts (there are no known life cycles for rhytidotids, but because they inhabit marine turtles it is unlikely they use anurans as second intermediate hosts.

Recent phylogenetic analyses of a small number of plagiorchioid species based on partial sequences of 1sr DNA (Tkach et al., 2000, 2001) have corroborated parts of the morphologically based hypothesis, most importantly that plagiorchiforms having Y-or V-shaped excretory vesicles form a clade, whereas those having I-shaped excretory vesicles, the traditional Macroderoididae, are paraphyletic and basal to them. This corroborates the placement by Thatcher (1963) of Parallopharynx in the Plagiorchiata. The molecular analysis also supported a close relationship between the Telorchiidae and Haematoloechidae within the Plagiorchiata (Plagiorchioidea of Yamaguti, 1971; Brooks et al., 1989; Brooks and McLennan, 1993). Future morphological and molecular study will undoubtedly clarify the relationship between Parallopharynx and the Telorchiidae.

The absence of the kind of phylogenetic assessment discussed above means that no synapomorphy has ever been proposed specifically for Parallopharynx. We have noted 3 unusual characters common to all 4 species of Parallopharynx that may prove to be synapomorphies for the genus: (1) the paired lateral lappets on the oral sucker (if synapomorphic for Parallophar$y n x$, they are convergently evolved in other related taxa); (2) the tripartite lappets at the anterior end of the pharynx; and (3) having sinistral ceca longer than dextral ceca. We hereby emend the generic diagnosis to include these traits.

On the basis of our examination of type and voucher specimens of all 4 spp., we provide the following artificial key to the species of Parallopharynx:

1a. Long slender body shape, maximum width less than $12 \% \mathrm{TBL}$, posterior extent of the cirrus sac more than 2 ventral sucker lengths from the posterior margin of the ventral sucker ... 2

1b. Stout body shape, maximum width greater than $12 \%$ total body length, posterior extent of cirrus sac less than 2 ventral sucker lengths from posterior margin of the ventral sucker ..... 3

2a. Oral sucker less than 150 , oral sucker-ventral sucker width ratio $1: 1$, metraterm extending from genital pore to posterior end of ventral sucker . . . . . . . . . . . matternae

$2 b$. Oral sucker greater than 150 , oral sucker-ventral sucker width ratio less than 1:0.8; distal extent of metraterm to midlevel of ventral sucker .................. arctus

3a. Distance between posterior margin of ovary and anterior margin of anterior testis more than 2 testis lengths, testes contiguous, or within 1 testis length $\ldots \ldots \ldots \ldots \ldots \ldots$ jonesi

3b. Distance between posterior margin of ovary and anterior margin of anterior testis less than 1.5 testis lengths, distance between testes more than 1.5 testis length . . . . . . . gonzalezi.

Species of Parallopharynx have been reported previously inhabiting iguanian lizards representing the Iguanidae (iguanas), Corytophanidae (basilisks), and Polychrotidae (anoles). This is the case thus far for the inventory of parasites of vertebrates in the ACG. Among iguanids; we have examined 2 specimens of C. quinquecarinata, 1 of which was infected with a single specimen of $P$. gonzalezi, as well as 32 specimens of $C$. similis and 4 specimens of Iguana iguana, none of which was infected with Parallopharynx. Among corytophanids, we have examined 7 specimens of $B$. basiliscus, 2 of which were infected with $P$. matternae, and 1 of which was infected with $P$. jonesi, as well as 3 specimens of Corytophanes cristatis, none of which was infected with Parallopharynx. Finally, we have examined 124 specimens of 9 species of Norops (= Anolis in earlier literature), namely $N$. biporcatus, $N$. capito, $N$. carpenteri, $N$. cupreus, $N$. humilis, $N$. limifrons, $N$. oxylophus, $N$. pachypsus, and $N$. tropidolepis, and have found specimens of $P$. jonesi in $N$. oxylophus and $N$. biporcatus. We have not found Parallopharynx spp. in any other vertebrate species within the ACG. With this report, host records for species of Parallopharynx include: $P$. arctus in the corytophanid $B$. vittatus, the polychrotid $N$. biporcatus, and an unidentified iguanid; $P$. gonzalezi in the corytophanid Basiliscus sp. and the iguanids Ctenosaura s. similis and $C$. quinquecarinata; $P$. jonesi in the polychrotids $N$. oxylophus (syn. Anolis lionotus) and $N$. biporcatus and the corytophanid B. basiliscus; and P. matternae in the corytophanid $B$. basiliscus.

\section{ACKNOWLEDGMENTS}

We are grateful to the scientific and technical staff of the ACG for support of this study, in particular: Elda Araya, Roger Blanco, Carolina Cano, Maria Marta Chavarría, Felipe Chavarría, Roberto Espinoza, Dunia Garcia, Guillermo Jimenez, Elba Lopez, Sigifredo Marin, Alejandro Masis, Calixto Moraga, Fredy Quesada, and Petrona Rios. We also thank Dan Janzen and Winnie Hallwachs, scientific advisers to the ACG, for their support. Host necropsy and parasite collections were made by D.R.B., Elda Araya, Sara Brant, Calixto Moraga, and Petrona Rios. We also thank Pat Pilitt (USNPC, Beltsville) and Gerardo Ponce de Leon (Universidad de Mexico) for specimen loans. This study was funded by a research grant from the Natural Sciences and Engineering 
Research Council (NSERC) of Canada to D.R.B. V.V.T. was supported by Grant 0132289 from the National Science Foundation.

\section{LITERATURE CITED}

Brenes, R., G. Arroyo, and F. Montero-Gei. 1960. Helmintos de la republica de Costa Rica XVI. Parallopharynx gonzalezi n. sp. (Trematoda: Plagiorchidae). Revista Biologia Tropical 8: 233-237.

Brooks, D. R., S. M. BANDONI, C. A. MACDONALD, AND R. T. O'Grady. 1989. Aspects of the phylogeny of the Trematoda Rudolphi, 1808 (Platyhelminthes: Cercomeria). Canadian Journal of Zoology 67: 2609-2624.

, D. A. MCLennan. 1993. Parascript: Parasites and the language of evolution. Smithsonian Institution Press, Washington D.C., 429 p.

, R. T. O'GRADY, AND D. R. GLEN. 1985. Phylogenetic analysis of the Digenea (Platyhelminthes: Cercomeria) with comments on their adaptive radiation. Canadian Journal of Zoology 63: 411-443.

Caballero y Caballero, E. 1946. Estudios helminthógicos de la región onchocerosa de Mexico y la Republica de Guatemala. Trematoda II. Presencia de Paragonimus en reservorios naturales y descripción de un neuvo género. Anales del Instituto de Biología, Universidad Nacional Autónoma de México 17: 137-165.

NEILAND, K. 1961. The helminth fauna of Nicaragua. II. Observations on Parallopharynx arctus Caballero, 1946. Journal of Parasitology 47: 913.

SCHELL, S. 1985. Handbook of trematodes of North America north of Mexico. University Press of Idaho, Moscow, Idaho, $263 \mathrm{p}$.

Thatcher, V. E. 1963. The trematodes of the basilisk lizard from Tabasco, Mexico. Anales del Instituto de Biología, Universidad Nacional Autónoma de México 34: 205-213.

TKACH, V., J. PAWLOWSKI, AND J. MARIAUX. 2000. Phylogenetic analysis of the suborder Plagiorchiata (Platyhelminthes, Digenea) based on partial 1sr DNA sequences. International Journal for Parasitology 30: 83-93.

,,-- , AND Z. SwIDERSKI. 2001. Molecular phylogeny of the suborder Plagiorchiata and its position in the system of digenea. In Interrelationships of the Platyhelminthes, D. T. J. Littlewood, and R. A. Bray (eds.). Taylor and Francis, London, U.K., p. 186-193.

UbelAKer, J. 1965. Parallopharynx jonesi, a new plagiorchiid trematode from the lizard, Anolis lionotus, in Nicaragua. Journal of Parasitology 51: 773-774.

YAMAGUTI, S. 1971. Synopsis of the digenetic trematodes of vertebrates. Keigaku Publishing Company, Tokyo, Japan, 1074 p.

. 1975. A synoptical review of life histories of digenetic trematodes of vertebrates: With special reference to the morphology of their larval forms. Keigaku Publishing Company, Tokyo, Japan, $575 \mathrm{p}$. 